\title{
The Concept of Islamic Education as a Scientific Discipline
}

\author{
Siti Aminah \\ UIN Sulthan Thaha Saifuddin Jambi \\ E-mail: sitiaminah@uinjambi.ac.id \\ Sinta Rahmatil Fadhilah \\ UIN Sulthan Thaha Saifuddin Jambi \\ E-mail: sintarahmatilfadhilah@uinjambi.ac.id
}

\begin{abstract}
This paper begins with a big consideration of an education which is the main source of development. Education always provides updates and developmenst. As one of the religions that is very existential among mankind, Islam contributes in education. As an applied science, Islamic education has relations to knowledge and humans. Thus, Islamic Education is one of the scientific disciplines that specifically exist among other scientific disciplines. If Islamic education is a scientific discipline, it must be scientifically academic. Even though it is academic, Islamic education is not subject to modern culture that tends to be anti-religious. Islamic education still prioritizes the al-Qur'an, Sunnah, the opinions of the prophet's companionships, ulamas, and Muslim scientists as the main sources. This paper aims to describe Islamic education as a scientific discipline. This paper is based on library research whose main source is writings related to Islamic education and scientific disciplines, as well as other relevant writings to be references in this paper.
\end{abstract}

Keywords: Islamic education, scientifi disciplines.

Abstrak: Tulisan ini berawal dari kesadaran bahwa pendidikan merupakan sumber pokok suatu perkembangan. Pendidikan selalu memberikan pembaharuan dan mengalami perkembangan. Sebagai salah satu Agama yang sangat eksistensial pada kalangan umat manusia, Islam memberikan kontribusi dalam hal pendidikan. Sebagai ilmu terapan pendidikan Islam memilki keterikatan antara pengetahuan dengan manusia, sehingga Ilmu Pendidikan Islam sudah tentu sebagai salah satu disiplin keilmuan yang khusus berdiri di antara disiplin keilmuan yang lain. Jika pendidikan Islam sebagai suatu disiplin ilmu maka pendidikan Islam harus bersifat ilmiah akademik, walaupun bersifat akademis pendidikan Islam tidak tunduk kepada budaya modern yang cenderung anti agama. Pendidikan Islam tetap menjadikan al-Qur'an, Sunah, pendapat para sahabat, ulama, dan ilmuan muslim sebagai sumber utama. Sehingga tulisan ini bertujuan untuk menguraikan tentang pendidikan Islam sebagai suatu disiplin ilmu. Tulisan ini berbasis penelitian pustaka yang sumber utamanya adalah tulisan-tulisan terkait pendidikan Islam dan disiplin ilmu, serta tulisan lain yang relevan yang menjadi rujukan dalam tulisan ini.

Kata-kata kunci: pendidikan Islam, disiplin ilmu. 


\section{Introduction}

The development of education in this contemporary era has been very progressive, even in Islamic campuses, Islamic education is an obligation that must be completed by students, and it is real evidence that Islamic education cannot be underestimated. As Sigit Dwi Laksana stated in his article that Islamic education does not only form highly competitive human resources, but also determines the social changes that occur in society in accordance with the establishment of Islamic values. It is because the science of Islamic education greatly contributes in shaping character and personality which is in accordance with the provisions of the al-Qur'an and Hadith. In addition, Islamic education also plays an important role in shaping the character of the nation in achieving the ideals and goals of national education. ${ }^{1}$

Islamic education as an applied science in order to develop education is certainly inseparable from the various problems that haunt it; starting from the epistemology of science itself, its sources, the benefits of its presence and many other problems that arose when it was first born. Islamic education as a form of science discusses almost all other scientific aspects and touches the aspects of humanity, from reason, physical, psychological, moral, aesthetics and so on. Therefore, more or less, it must have a connection between this knowledge and humanity dimensions that is why it is no wonder that later Islamic education becomes a special scientific discipline.

It is known that the main source of Islamic education as a scientific discipline is the holy book of the Qur'an and the Sunnah of the Prophet Muhammad as well as the opinions of the prophet's companions and scholars or Muslim scientists ${ }^{2}$. As a scientific discipline, Islamic education is scientific in nature but it is not fully subject to modern culture which tends to be antireligious, or keeps the science away from religious interference. For example, the culture of modern science (West) which views the nature, methods, structure of science and religion are very different. Religion assumes or views a problem from a normative perspective (how it should be) while science views the science from an objective perspective (how it is). Religion views problems and their solutions through God's guidance, while science treats problems through experiments and human ratio solely. ${ }^{3}$

Islamic education does not have a secular characterics as found in western culture. The word 'Islamic' behind the word 'education', not only becomes a source of motivation, inspiration, sublimation, and integration for

\footnotetext{
${ }^{1}$ Moh. Fachri, Urgensi Pendidikan Agama Islam Dalam Pembentukan Karakter Bangsa, At-Turas, Vol. 1, No. 1, 2014, p. 131-168.

2 Muhammad Arifin, Kapita Selekta Pendidikan (Islam dan Umum), Jakarta: Bumi Aksara, 1993, p. 15.

${ }^{3}$ Abuddin Nata, Ilmu Pendidikan Islam dengan Pendekatan Multidisipliner, Jakarta: PT Raja Grafindo Persada, 2010, p. 15.
} 
the development of education, but also becomes the characteristics of the Islamic education itself.

From the previous description, the discussion related to Islamic education as a scientific discipline in this paper covers several problems, they are: what is meant by Islamic education as a scientific discipline? What are the qualifications and objectives that must exist in education as a scientific discipline? This research is a research based on library research whose main source is related to Islamic education and scientific disciplines as well as other sources that support this paper.

\section{Islamic Education as a Scientific Discipline}

The term of formal education is known as education which is derived from the word to aducate, meaning to raise, educate. In the dictionary of education, the meaning of education is a collection of all processes that enable a person to develop abilities, attitudes, and forms positive behavior in the society where he or she lives. The education term is a social process when a person is faced with the influence of a selected and controlled environment (especially the social environment), so that they can have social abilities and develop their individuality optimally. ${ }^{4}$ In other words, education is a process that has a purpose which is usually endeavored to create certain patterns of behavior in students. ${ }^{5}$

As for Islam, in language, it means resignation and obedience. The term of Islam is used as the name of the religion and life order brought by the prophet Muhammad SAW, through the revelations from Allah SWT, which exist in the Al-Quran and Hadith. Islam is one of the religions in the world with its own values and norms based on the teachings of Islam itself.

Thus, Islamic education is a deliberate activity of guidance to achieve a Muslim personality which is related to the physical, spiritual, intellectual and moral dimensions. Islamic education is a process of guidance of an educator so that the physical, spiritual and intellectual aspects grow and develop towards the formation of Islamic personality, family and society.

There has been a number of studies to find out how the basic principles of Islamic teachings developed in various historical periods up to present. The periodization of the history of Islamic education development is divided into the following periods: 6

\section{Early education era (formation era)}

This period consists of the era of the apostles and the companioship (571 AD - $661 \mathrm{AD}$ ) and the era of the Umaiyah kingdom (661 AD - 705 AD) which at

\footnotetext{
${ }^{4}$ Beni Ahmad Saebani and Hendra Akhdiyat, Ilmu Pendidikan Islam, Bandug: Pustaka Setia, 2009, p. 39.

${ }^{5}$ Hasan Langgulung, Manusia dan Pendidikan: Suatu Analisis Psikologi dan Pendidikan, Jakarta: Alhusna Zikra, 1995, p. 32.

${ }^{6}$ Hasan Langgulung, Manusia dan Pendidikan, p. 10.
} 
this time the characteristics of Islamic education are still purely based on the Qur'an and Hadith, for seetting the foundation of Islam, the principle of education was still based on the Qur'an. At that time Islamic education was still synonymous with Islamic preaching efforts in accordance with the development of Islamic religion. The actualization of education still used written words as a means of communication, as an effort to pave the way for learning foreign languages, still accentuated Arabic elements and education took place in the mosques and library.

\section{The Golden Age}

This era was during the Abbasid Empire (750 AD - 1258 AD). At this time the characteristics of Islamic education as a scientific discipline had begun to emerge, educational institutions had begun to be established. Many experts in the field of science and education had begun to experience scientific development and translation of old books from various languages into Arabic was conducted.

\section{The Decline Era}

This period was during the Ottoman Empire (1517 AD - 1917 AD). At this time education was more on establishing military strength while the development of science and thought was neglected. Finally, Islamic countries under the Turkey kingdom were facum for four centuries.

\section{The New Era}

This era is in the twentieth century until now, which has shown progress in science and technology-based knowledge.

In order to understand the concept of Islamic education, it is necessary to reiterate that the word Islam is a key word that functions as an attribute, affirmation, and characteristic of the word education. As a scientific discipline, Islamic education has the main duty of collecting the insights or views of education contained in its main sources with the help of opinions from companions of The Prophet, scholars or scientists. In these main sources, there are fundamental materials that contain educational values or educational implications that are still scattered about. To be formed into a scientific Islamic education, these materials need to be systematized and theorized in accordance with the rules (norms) established in the world of science.

The academic world of science has established norms of requirements and criteria that must be met by a scientific science. The stipulated scientific requirements appear to be secular in nature, in the sense that it eliminates a perspective or concept in many aspects, which involves divine values which are seen as irrational, but metaphysical. 
Education is likened to a house consisting of poles, floors, walls or stairs, etc. That is education as a scientific discipline which consists of curriculum, counseling, administration, teaching, and assessment. ${ }^{7}$

\section{The Criteria of Islamic Education as a Scientific Discipline}

Islamic education is a classic education that has unique characteristics and is full of dynamics. The dynamics of Islamic education cannot be separated from the problems that exist around it, such as problems related to the system being developed, scientific dichotomy, curriculum, and the orientation of the resulting Human Resources output. However, Islamic education will be able to minimize these dynamics if it is able to adapt with changes in the modern world. One of them is by making Islamic education as a scientific discipline. Thus, Islamic education will be able to follow other scientific developments without leaving Islamic values. The requirements that need to be fulfilled by Islamic education as a scientific discipline, according to social science in general, include the following: ${ }^{\circ}$

1. Having a clear and distinctive educational object of discussion supported by other relevant sciences.

2. Having theories, assumptions, perspectives or hypotheses that are educational in nature based on Islamic teachings.

3. Having a method of analysis that is in accordance to the demands of a scientific style; education that has Islamic characteristics or values on the basis of approaches that are relevant to that scientific style and characteristics.

4. Having definitive scientific structures that related to one another as an independent scientific system (not dependent on other scientific systems).

Islamic education when viewed from the human cultural life point of view is eventually one of the means of human culture itself. As a media, education can be functioned to direct the growth and development of human life (as personal and society to the optimal point of being able to obtain welfare in the world and happiness in the hereafter). In this case, education as a means of culture is very dependent on the educators. Both theoretically and practically, in carrying out their duties, internal factors such as the talents or traits of students, and external factors such as the environment in all its dimensions, become the process of educators' efforts.

Therefore, to obtain an overview of patterns of thought and action in the implementation of Islamic education in particular, a theoretical framework that contains scientific concepts of Islamic education is needed. In

\footnotetext{
${ }^{7}$ Hasan Langgulung, Asas-Asas Pendidikan Islam, Jakarta: Alhusna Zikra, 2000, p. viii.

${ }^{8}$ Nur Uhbiyati, Ilmu Pendidikan Islam, Bandung: Pustaka Setia, 1999, p. 20.
} 
other words, to obtain a success in the process of Islamic education, it requires knowledge of Islamic education, both theoretical and practical.

There are several reasons for considering the importance of theoretical Islamic education, they are: ${ }^{9}$

1. Education as an effort to shape the human personality must go through a long process. In this formation process a careful calculation is needed based on appropriate perspective and thoughts or theories. so that failure or missteps in the formation of students can be avoided.

2. Islamic education is particularly based on Islamic religious values. Besides to instill or form an attitude of life that is imbued with these life values, it also develops knowledge. Therefore, efforts cannot be made solely based on trial and error or on the basis of desire and motivation without being based on educational theories which can be justified scientifically.

3. Islam as a revealed religion sent by Allah with the aim of prospering and making human life happy in the world and in the hereafter can have a functional and actual meaning to human beings if it is developed through a systematic process of educating.

4. The scope of Islamic education includes all areas of human life, where humans are able to take advantage of the good indeeds intention and the formation of Islamic attitudes and values individually through an educational process that runs on the principles of educational science.

5. Theories, hypotheses and educational assumptions derived from Islamic teachings have not been scientifically compiled even though the raw materials have been available in both the holy books of the alQuran and al-Hadith. These a scientific systematic arrangement is required that is supported by extensive research results.

Meanwhile, the practical function of Islamic education cover three main tasks ${ }^{10}$ :

1. It proves Islamic educational theories which summarize Islamic aspirations or ideals that must be realized in order to become reality.

2. It provides information about the implementation of education in all its aspects for the development of Islamic education. It provides valuable input to this knowledge.

3. It becomes a corrector of the weakness of the theories held by Islamic education, so that the possibility of a meeting between the two of them increasingly influences each other.

As with theoretical education in the implementation of practical education, approaches are needed to allow the expansion of educators' views

${ }^{9}$ Nur Uhbiyati, Ilmu Pendidikan Islam, p. 22.

${ }^{10}$ Nur Uhbiyati, Ilmu Pendidikan Islam. 
of the educational object at hand, as long as this approach is related to educational obligation.

Islamic acceptance of science is evaluative based on the values it outlines with such acceptance that education will have its own knowledge. Islam's evaluative roles towards science often appear in the application of the results. Before the knowledge is produced, the study is conducted; the moral responsibility of the scientists should also be consideridered, especially the choice of objects that the science examines. Some education experts believe that the object of education is the educational situation. This situation can be changed, managed and perfected. Students should not be manipulated as educational objects. They are free subjects with dignity and have free will to carry out their life's mission.

Based on the reasons mentioned, it can be concluded that Islamic education is a science based on Islam. The scope is the situation in which Islamic education is taking place, and the method is the scientific method. Every theory in Islamic education must have an Islamic moral responsibility. Therefore, it is natural that in Islamic education books there are verses or hadiths that support the theory. ${ }^{11}$

In this review, it is revealed how Islamic perspective of educational problems may be applied through a process that is in accordance to the principles of educational science in general. In other words, the science of Islamic education in its theories contains the conformity of views with theories in science, especially those concerning students, educators, media, surroundings and aspirations. So it is clear that it appears that Islamic educational theory contains scientific values that are valid in the world of science, especially in the world of education.

If Islamic education has become a scientific and practical science, then it will be able to function as a more effective and efficient media of civilizing human beings with Islamic values. People know and acknowledge that Islam has been articulated through its preaching in society until now. The process of Islamic education has referred to a society of various cultures and structures and so far its services have appeared to color human attitudes and personalities which are shaped by the positive impacts of its sustainable process.

\section{Purpose of Islamic Education as a Scientific Discipline}

As a scientific discipline, Islamic education is a collection of ideas and intellectual concepts structured and needed through experience and knowledge. Thus, experiencing and knowing is the initial reinforcement of human conceptualization which continues to form that knowledge. For this reason, Prophet Adam was taught the names of objects first as a conceptual basis for the formation of his knowledge in the Al-Qur'an Surat al-Baqarah verse 31:

\footnotetext{
${ }^{11}$ Hery Noer Aly, Ilmu Pendidikan Islam, Jakarta: Logos Wacana Ilmu, 1999, p. 26.
} 
Then He gave Adam knowledge of the nature and reality of all things and everything, and set them before the angels and said: "Tell Me the names of these if you are truthful."12

The Islamic education must be based on dialogical ideas with empirical experiences consisting of facts or information to be processed into valid ones in which a scientific science is based.

As a scientific discipline, Islamic education is a continuous effort to provide knowledge, skills and appreciation of the Islamic provisions based on the Qur'an and as-Sunnah. With Islamic education, humans can improve attitudes, skills, personalities and perspective of life as Allah's worshipers who have the responsibility to develop themselves, society, the environment, the State and religion to achieve a good life in the world and peace at the end. Even though the aims of education are high ideals, if the methods and materials are inadequate, the educational process will fail. Therefore, an educational goal will not appear in a process whose method and content are resistant.

Universal educational goals have been formulated in world Islamic education seminars, in Islamabad in 1980 which was agreed upon by all scholars of Islamic education experts from Islamic countries. This formulation reflects the ideals of Islam as contained in the Qur'an as its essence. The goal of Islamic education which is in line with the demands of the Qur'an is none other than the attitude of total submission to Allah, who we has pledged in our daily prayers. (Surah al-An'aam 162):

Say, "Surely my prayer, my worship, my life, and my death are all for Allah-Lord of all worlds. ${ }^{13}$

Thus, we do not want other formulas established by thinkers whose orientation does not refer to the instructions of the Qur'an. For Muslims the Qur'an is the basic criterion to determine everything in life based on Islamic values. ${ }^{14}$

Through these various opinions, it is clear that Islamic education has a fundamental and strategic objective. It is believed to be fundamental, because through Islamic education, theories, concepts, principles can be used in formulating various components of education: vision, mission, goals, curriculum, teaching and learning process, etc. Futhermore, it is believed to be strategic, because with Islamic education, the educational process will run systematically and effectively in order to have qualifiied graduates in all aspects; either knowledge, insight, skills, mental spirituality, morals, or personality.

12 Departemen Agama RI, Al-Qur'an Al-Karim dan Terjemahannya, Jakarta: Maghfiroh Pustaka, 2006, p. 6.

13 Departemen Agama RI, Al-Qur'an Al-Karim dan Terjemahannya, p. 150.

${ }^{14}$ Arifin, Kapita Selekta Pendidikan (Islam dan Umum), p. 17. 
The backwardness of Islamic education occuring today is because educational activities that generally take place in society still carried out conventionally, only with intention and enthusiasm, but it is not supported by established theories and concepts whose effectiveness has been proven. ${ }^{15}$ One of the reasons why the Islamic world has left behind is that the education held does not refer to the current situation. However, it is still comfort zone of under the umbrella of Islam glory in the past. The transformation of Islamic education into a scientific discipline is an effort to reduce the dichotomy crisis with modern science. So that the theoretical framework of Islamic education is in accordance with the development of the modern world and at the same time reflects Islamic values, culture and norms.

\section{Closing}

Islamic education as a scientific discipline is education is likened as a house consisting of poles, floors, walls or stairs and others. That is the education as a discipline which consists of curriculum, counseling, administration, teaching, and assessment. The criteria of Islamic education as a scientific discipline is to have a clear object of discussion, to have theories and assumptions, to have an analysis method that is in accordance with the demands of a scientific style, and a definitive scientific structure containing an unanimity parts related to each other as an independent system.

The purpose of Islamic education as a scientific discipline is because it has a fundamental and strategic objective. It is stated to be fundamental, because through Islamic education, theories, concepts, principles can be used in formulating various components of education: vision, mission, goals, curriculum, teaching and learning process, etc. Futhermore, it is believed to be strategic, because with Islamic education, the educational process will run systematically and effectively. To be formed into a scientific Islamic education, these sources need to be systematized and theorized in accordance to the rules (norms) established in the world of science. To fulfill other requirements, the scientific Islamic education must have a clear object of discussion, have educational's theories, assumptions and hypotheses which still have Islamic teachings principles, as well as have clear analytical methods and have a definitive scientific structure.

Islamic acceptance on science is evaluative based on the values it outlines. With this acceptance, education will have its own knowledge. Islam's evaluative role towards science often stands out in the application of the results. Before the knowledge is produced, the study is carried out, the scientists should also consider the choice of objects that the science they examine as part of their moral responsibility. Some education experts believe that the object of education is the educational situation. This situation can be changed, managed and perfected. The word Islam is a character or keyword

${ }^{15}$ Abuddin Nata, Ilmu Pendidikan Islam dengan Pendekatan Multidisipliner, p. 22. 
that functions as an attribute, affirmation, and characterist in "Islamic Education". The periodization of Islamic education development is divided into four periods, starting from the Prophet Muhammad's era to present time. From these periods, the development of science experienced a golden peak in the second period (750 AD - $1258 \mathrm{AD}$ ).

Islamic education must be based on dialogical ideas with empirical experience consisting of facts or information to be processed into valid ones, in which a scientific knowledge is based. It can be concluded that Islamic education is a science based on Islamic principles or values. The scope is the situation in which Islamic education is taking place, and the method is the scientific method. Every theory in Islamic education must have an Islamic moral responsibility.

Therefore, no wonder if in Islamic education books there are verses or hadiths that accompany the theory in order to provide knowledge, skills and appreciation of the Islamic provisions based on the Qur'an and as-Sunnah. By having this Islamic education, people can develop attitudes, skills, personalities and views of life as Allah's worshipers who have the responsibility to develop themselves, society, the environment, the State and the religion to achieve a good life in the world and peace at the end. Therefore, the goal of Islamic education is in line with the demands of the Qur'an. It is none other than the attitude of total submission to Allah SAW.

\section{Bibliography}

Aly, Hery Noer, Ilmu Pendidikan Islam, Jakarta: Logos Wacana Ilmu, 1999.

Arifin, Muhammad, Kapita Selekta Pendidikan (Islam Dan Umum), Jakarta: Bumi Aksara, 1993.

Budiyanto, Mangun, Ilmu Pendidikan Islam, Yogyakarta: Ombak, 2013.

Departemen Agama RI. Al-Qur'an Al-Karim Dan Terjemahannya. Jakarta: Maghfiroh Pustaka, 2006.

Fachri, Moh, Urgensi Pendidikan Agama Islam Dalam Pembentukan Karakter Bangsa, At-Turas 1, No. 1, 2014.

Jaafar, Noornajihan, Halim Tamuri, Nurul Asiah Fasehan Muhammad, Norzulaili Mohd Ghazali, Robiatul Adawiyah Mohd, Norakyairee Mohd Raus, and Syed Najihudin Syed Hasan, The Importance of Self-Efficacy: A Need for Islamic Teachers as Murabbi, ELSEVIER 69, no. Social and Behavior Science, 2012.

Laksana, Sigit Dwi, Urgensi Pendidikan Islam Dalam Perubahan Sosial Di Masyarakat, Jurnal Aristo, Vol. 4, No. 2, 2016.

Langgulung, Hasan, Asas-Asas Pendidikan Islam, Jakarta: Alhusna Zikra, 2000.

-_- Manusia Dan Pendidikan: Suatu Analisis Psikologi Dan Pendidikan, Jakarta: Alhusna Zikra, 1995. 
Mawardi, Imam, Pendidikan Islam Transdisipliner Dan Sumber Daya Manusia Indonesia, Jurnal Pendidikan Islam UIN Sunan Gunung Djati, Vol. XXVIII, No. 2, 2013.

Nata, Abuddin, Ilmu Pendidikan Islam Dengan Pendekatan Multidisipliner, Jakarta: Raja Grafindo Persada, 2010.

Saebani, Beni Ahmad, and Hendra Akhdiyat, Ilmu Pendidikan Islam, Bandug: Pustaka Setia, 2009.

Uhbiyati, Nur, Ilmu Pendidikan Islam (IPI), Bandung: Pustaka Setia, 1999. 
The Concept of Islamic Education as a Scientific Discipline 